\title{
STUDI KOMPARASI PELAYANAN PERIZINAN TERPADU SATU PINTU (PPTSP) DALAM PENERAPAN BUDAYA ORGANISASI
}

\author{
Rhini Fatmasari* \\ Eka Vidya Putra** \\ Sri Sumiyati ${ }^{* * *}$
}

\begin{abstract}
The integrated of one-stop service is one of the major breakthroughs made by the government in order to improve public services, its specialized in the field of licensing through Permendagri number 24 concerning about Pelayanan Perizinan Terpadu Satu Pintu (PPTSP). In Government regulation district/city administration are required to have PPTSP Institutions, not only formality in the sense of institutional institutions but also in terms of value and mechanisms. General trend in Indonesia is difficult to start a formal business due to hit on the difficulty of the licenses. Although, all parties aware that businesses, especially Small and Medium Enterprises (SMES) is one of the main pillar of the nation's economy. Overall formation of the PPTSP can be said to be successful in the district/city. But the success is not evenly distributed in the context of the development of organizational culture. If the formation of institutions PPTSP more leads to the formation of organization and mechanisms that are supported by regulatory which is the organization's culture is more directed at the behavior.The research was conducted in three PPTSP namely District Sragen, District Solok and District 50 Kota by comparing the third success and how to develop organization culture. The results showed that the success 50 Kota in develop of public service supported by the formation of organizational culture continuously. Formation of organization culture done with socializing the values espoused in organization, particularly cultural services to consumers. Success of District Sragen not be separated from the region's ability to internalize the values of service to staff 50 Kota. The same think was not seen in District Solok and District 50 Kota.
\end{abstract}

Keywords: public services, Pelayanan Perizinan Terpadu Satu Pintu (PPTSP), organizational culture, internalization of values

Rhini Fatmasari adalah Dosen Program Studi Pendidikan Ekonomi PIPS Universitas Terbuka Jakarta.rhiens2009@gmail.com

** Eka Vidya Putra adalah Dosen Jurusan Sejarah FIS Universitas Negeri Padang. ekavidyaputra@gmail.com

Sri Sumiyati adalah Dosen Program Studi Pendidikan Ekonomi PIPS Universitas Terbuka Jakarta. sumi@ut.ac.id 


\section{PENDAHULUAN}

\begin{tabular}{ccc}
\multicolumn{2}{c}{ Pembenahan } & \multicolumn{2}{c}{ pelayanan } \\
birokrasi yang selama ini \\
cenderung dicitrakan
\end{tabular} menjadi wacana, baik di lingkungan masyarakat umum maupun di lingkungan pemerintahan itu sendiri. Pada level publik misalnya muncul tuntutan yang sangat kuat agar pemerintah konsisten untuk melaksanakan reformasi birokrasi. Pemerintah dinilai oleh banyak pihak lamban melakukan reformasi. Telah lebih dari sewindu perjalanan reformasi hampir tidak ada loncatan yang berarti dalam pada sektor birokrasi ini.

Sedangkan di tingkat pemerintahan, harus diakui bahwa secara legal formal pembenahan pelayanan publik terus mendapat perhatian khusus. Sejumlah kebijakan diterbitkan agar penyelenggaraan pelayanan prima segera terealiasi. Keinginan tersebut setidaknya sejalan dengan apa yang menggenjala di ranah praktis. Pada beberapa tahun terakhir hampir seluruh pejabat publik, menjadikan isu pelayanan prima sebagai simbol kepemimpinan. Apa yang terjadi tersebut telah mendapat dukungan teoritis. Terus menguatnya isu reformasi birokrasi, tidak dapat dilepaskan dari pelaksanaan otonomi daerah. Secara teoritis pelaksanaan otonomi daerah akan berdampak pada tiga perubahan yaitu; (1) political equility, suatu kondisi di mana terbukanya ruang bagi publik untuk relatif mudah mendapatakan akses ke ruang- ruang birokrasi. Keterbukan tersebut pada akhirnya menciptakan checks and balances; (2) local accountability, berkaitan dengan transparansi dan mekanisme akuntabilitas terhadap apa yang telah dilakukan; dan (3) local responsibility, yakni adanya jaminan untuk memberikan pelayanan publik yang prima.

Bagaimana perubahan itu terjadi ? menjadi pertanyaan yang menarik untuk terus dicermati. Salah satu persoalan birokrasi publik yang sering mendapat sorotan dan dapat menjadi etalase pelayanan publik secara keseluruhan adalah pelayanan jasa perizinan. Kecenderungan umum yang terjadi adalah sulitnya memulai usaha formal di Indonesia karena terbentur pada sulitnya mengurus perizinan. Walaupun, semua pihak menyadari bahwa dunia usaha, khususnya Usaha Kecil Menengah (UKM) adalah salah satu pilar utama ekonomi bangsa. Bahkan ketangguhan UKM sebagai unit usaha yang melekat langsung dalam urat nadi perekonomian rakyat setidaknya sudah terbukti semasa krisis ekonomi 1998. Permasalahan pengurusan izin usaha selama ini tidak dapat dilepaskan dari proses legalisasi di tingkat birorasi. Prosedur yang berbelit-belit, banyak dan tumpang tindihnya persyaratan, ketidak jelasan biaya, dan rata-rata lamanya waktu penyelesaian perizinan (dalam artian tidak adanya kepastian waktu), ditambah tidak tersedianya informasi yang cukup 
memadai merupakan kondisi pengurusan perizinan untuk usaha di negeri ini. Maka wajar jika banyak pengusaha menjadi enggan untuk mengurus izin usaha. Berdasarkan data Badan Pusat Stratistik (1996) hanya $19,8 \%$ pengusaha yang memiliki surat izin usaha. Selanjutnya hasil penelitian Bank Dunia menunjukan, bahwa untuk memulai usaha di Indonesia ratarata dibutuhkan 151 hari, melewati 12 prosedur, dan membutuhkan biaya sekitar 130,7\% pendapatan perkapita: Data tersebut menunjukkan bagaimana potret pelayanan birokrasi di Indonesia yang masih jauh dari bentuk pelayanan efektif dan prima.

Berkaitan dengan pelayanan jasa perizinan ini, pemerintah melakukan terobosan yang patut dapat pujian yaitu dikeluarkannya Permendagri nomor 24 tentang Pelayanan Perizinan Terpadu Satu Pintu (PPTSP). Dalam Permendagri itu permerintahan kabupaten/ kota diwajibkan memiliki lembaga PPTSP. Tidak sebatas formalitas kelembagaan dalam artian institusi tapi juga lembaga dalam artian mekanisme dan nilai. Kebijakan nasional ini dapat dikategorikan sebagai loncatan kuantum dalam reformasi birokrasi khususnya dalam pelayanan jasa perizinan. Namun patut dicatat, baik berupa wacana maupun dalam penerapannya, konsep PPTSP sudah cukup lama berkembang dan diimplementasikan oleh Pemkab/Pemkot, bahkan jauh sebelum konsep PPTSP diluncurkan.
Sedangkan beberapa PPTSP mulai menunjukkan langkah maju, daerah tersbeut rata-rata daerah yang dinilai cepat merespon pembenahan pelayanan perzinan. Sejumlah daerah tersebut adalah Kabupaten Jembrana (2000), Kababupaten Sragen (2002), Kota Yogyakarta (2005), Kabupaten Solok (2005) dan Kababupaten Kebumen (2006). Sedangkan ditingkat provinsi, daerah yang cepat merespon lahirnya PPTSP adalah Provinsi Jawa Barat. Terdaftar sedikitnya 4 Pemkab/Pemkot yang sudah mencoba menerapkan inisiatif PPTSP (diantaranya Kota Cimahi, Kab. Indramayu, Kab. Majalengka \& Kab. Purwakarta). Walau tergolong baru keempat daerah tersebut telah melakukan perubahan mendasar.

$$
\text { Keberhasilan Kabupaten }
$$

Sragen yang telah sukses menjadi pionir pelaksanaan terlihat dari terlaksananya pelayanan yang cepat, mudah, transparan, dan pasti. PPTSP di Sragen melayani 52 perizinan serta 10 jenis pelayanan administrasi kependudukan yang masuk dalam kategori nonperizinan. Kecepatan pelayanan perizinan ini tercermin dari kepastian waktu yang maksimal hanya 12 hari.

Dampak dari kemudahan yang diberikan lewat PPTSP terlihat dari perbandingan kondisi ekonomi. Dalam kurun waktu satu tahun, investasi industri mikro, kecil, dan menengah di Sragen meningkat dari Rp 30,7 miliar menjadi Rp 35,2 miliar (naik 16,6 persen). Investasi industri besar juga meningkat dari 
Rp 110 miliar menjadi Rp 394,8 miliar (naik 213 persen). Demikian juga dengan penyerapan tenaga kerja sektor industri meningkat dari 28.976 orang menjadi 41.800 orang (naik 44,29 persen). Selain itu, perusahaan yang mempunyai legalitas usaha pun meningkat, dari 5.299 perusahaan menjadi 6.913 persen (naik 30,1 persen) http://diswandi.wordpress.com/ Reformasi birokrasi khususnya dalam pelayanan perizinan telah dimulai oleh Kabupaten Solok jauh sebelum terbitnya Permendagri 24 tahun 2006. Pada tahun 1998 diterbitkan Keputusan Bupati Solok No 9 tentang Pembentukan Pos Pelayanan Umum Satu Pintu dan Penetapan Jenis-jenis Perizinan dan Pelayanan Umum yang Termasuk dalam Posyantu. Pengembangan selanjutnya Posyantu meluncurkan program yang mereka beri nama Posyantu Plus, program ini bertujuan untuk memberi kemudahan dalam layanan jasa perizinan sampai ketingkat lebih bawah (nagari-nagari). Selanjutnya Unit pelayanan ditingkatkan menjadi Kantor. Pengembangan tersebut sejalan dengan kebijakan Permendagri 24 tahun 2006. Dalam hal ini Kabupaten Solok termasuk kabupaten/ kota yang tergolong cepat merespon kebijakan tersebut.

Kenapa PPTSP di sejumlah daerah berkembang dan disejumlah daerah lainnya tidak berkembang? Dari sejumlah evaluasi yang pernah dilakukan, keunggulan dan kelemahan utama yang menentukan berhasil atau tidaknya reformasi birokrasi tersebut adalah kemampuan daerah menumbuhkan apa yang disebut dengan budaya organisasi birokrasi. Karena konsep pengembangan PPTSP sangat jauh berbeda dengan budaya organisasi yang selama ini tumbuh dalam birokrasi kita selama ini.

Budaya organisasi merupakan sistem makna bersama yang dianut oleh anggota-anggota yang membedakan organisasi itu dengan organsasi lain. Budaya merupakan perekat sosial yang membantu organisasi itu dengan memberikan arahan dan standar yang tepat tentang apa yang harus dilakukan oleh karyawan yang berada di dalam organisasi tersebut sekaligus juga memandu dan membentuk sikap serta perilaku karyawan. Tanpa budaya organisasi yang kuat, akan sulit bagi organisasi untuk mengaharapkan komimen yang tinggi dari karyawannya di dalam menunjang kinerja organisasi. Budaya organisasi yang telah terbentuk dengan baik dan mengakar pada keseluruhan pelaku organisasi akan memberikan dampak yang menguntungkan bagi performance organisasi.

Pada konteks ini, kegagalan dibanyak PPTSP adalah masih mengikuti budaya organisasi dalam birokrasi yang selama ini masih menganut paradigma dilayani, dan berorientasi "asal bapak senang". Sedangkan budaya organisasi PPTSP seharusnya menganut paradigma 
melayani dan berorientasi kepuasan pengguna jasa. Kondisi tersebut setidaknya tergambar dari pengembangan PPTSP yang masih sebatas usaha pembentukan lembaga dan sangat minim memperhatikan terbentuknya dan tumbuhnya budaya baru.

Selanjutnya untuk keluar dari jeratan tersebut, butuh satu penciptaan budaya organisasi baru dalam tubuh PPTSP. Tata cara, kebiasaan dan tradisi yang ada dalam satu organisasi saat ini tidak terbentuk dengan sendirinya, tapi sesuatu yang diciptakan kemudian dilembagakan menjadi satu nilai bersama.

\section{Permasalahan}

Reformasi birokrasi tidak hanya sebatas membangun institusi birokrasi terpenting lagi yaitu bagaimana berkembangnya budya organisasi serta bagaimana pertumbuhan budaya organisasi dibalik pembangunan institusi organisasi. Sehingga pada konteks ini penelitian ini menarik untuk dilakukan.

Mencermati fenomena tersebut maka penelitian ini akan mengajukan pertanyaan penelitian :

1. Bagaimana pembangunan institusi organisasi PPTSP dilakukan?

2. Bagaimana pertumbuhan budaya organisasi sebagai dampak dari pembangunan institusi organisasi?

\section{Tujuan Penelitian}

Penelitian ini bertujuan untuk melakukan kajian terhadap reformasi birokrasi pada unit pelayanan publik khususnya pada Pelayanan Perizinan Terpadu Satu Pintu (PPTSP) dan budaya organisasi yang berkembang sejalan dengan reormasi birokrasi tersebut.

\section{Manfaat Penelitian}

Penelitian ini bermanfaat bagi:

1. Pemerintah daerah setempat, sebagai acuan dalam memberikan pelayanan publik lebik efektif dan efisien di daerah tersebut

2. Akan menjadi acuan bagi Pemda lain dalam melakukan reformasi pelayanan publik.

3. Para peneliti selanjutnya sebagai salah satu bahan acuan tentang budaya organisasi dan pelayanan publik.

\section{KAJIAN PUSTAKA}

\section{Pelayanan Perizinan Terpadu Satu Pintu (PPTSP)}

Pelayanan Perizinan Terpadu Satu Pintu (PPTSP) merupakan satu layanan yang diberikan oleh pemerintah daerah yang difokuskan pada perampingan prosedur yang ada untuk meningkatkan efisiensi birokrasi pemerintah dan untuk menetapkan proses pelayanan umum yang ideal untuk situasi saat ini. Perampingan prosedur dimaksudkan sebagai upaya mengurangi langkah-langkah dan persyaratan yang tidak diperlukan 
sehingga dapat dikembangkan menjadi sistem dengan standar waktu dan kualitas pelayanan yang sesuai dengan apa yang diharapkan oleh masyarakat. Suksesnya pelaksanaan PPTSP merupakan cerminan kesusksesan pemerintah dalam menerapkan Good governance di daerah tersebut, karena salah satu indikator pelaksanaan good governance terlihat dari keberhasilan pelaksanaan layanan publik.

\section{Budaya Organisasi}

Budaya organisasi merupakan perangkat lunak, dengan keseluruhan konsep yang memiliki konsekuensi yang kuat. Budaya organisasi dalam pengertian umum merupakan reproduksi keseluruhan penggunaan simbol-simbol. Dasardasar budaya organisasi yang telah ada akan membimbing anggota organisasi untuk berperilaku dan bagaimana cara mereka dalam berintegrasi dengan konsumen, serta komitmen yang akan diberikan kepada organisasi. Tanpa budaya organisasi yang kuat, akan sulit bagi organisasi untuk mengaharapkan komimen yang tinggi dari karyawannya di dalam menunjang kinerja organiasi. Kotter and Heskett (1992) menemukan bahwa budaya organisasi merupakan salah satu factor yang menentukan keberhasilan organisasi, terutama kekuatan, strategi yang tepat, dan adaptasi budaya berhubungan dengan performance ekonomi dalam jangka panjang. Deshpande dan
Farley (2004) juga melihat adanya hubungan antara keterbukaan, orientasi eksternal dari budaya organisasi dan performance organisasi.

Budaya organisasi yang telah terbentuk dengan baik dan mengakar pada keseluruhan pelaku organisasi akan memberikan dampak yang menguntungkan bagi performance organisasi. Kotter and Heskett (1992) menyatakan bahwa budaya organisasi yang kuat merupakan pengerak kesuksesan organisasi. Hal ini terbukti dari hasil penelitian oleh Leslie de Chernatony and Susan Cottam (2008) yang menghubungkan antara budaya organisasi dan kesuksesan brand organisasi.

\section{Reformasi Budaya Organisasi}

Reformasi budaya organisasi dapat didevinisikan sebagai perubahan yang luas dari keadaan yang biasa dipakai, juga di dalam perencaan atau tidak direncanakan menuju pada kebiasaan lainnya. (Erdogan, 1997). Perubahan negatif atau positif yang terjadi pada dimensi alamiah, sosial, politik masyarakat mungkin memberikan pengaruh secara langsung atau tidak langsung pada budaya oranisasi. (Cesur, 1999; Ero“ glu, 1995; Simms, Price, Ervin, \& 1994; Susar, 2000).

Perubahan-perubahan yang terjadi di lingkungan luar organisasi juga akan memberikan rangsangangan terjadinya perubahan dalam sebuah budaya 
organisasi. Salah satunya adalah perubahan struktur dan bentuk organisasi. Seyda Seren dan Ulku Baykal (2007) menyatakan bahwa perubahan bentuk organisasi dari bentuk privat ke publik menyebabkan terjadi perubahan type kepemimpinan dari otocracy ke bentuk yang lebih demokratis, hal ini akan menyebabkan pula terjadinya perubahan dalam type kepemimpinan yang lebih demokratis. Selanjutnya perubahan demi perubahan ini akan memicu terjadinya perubahan dalam budaya organisasi secara keseluruhan. Selanjutnya terlihat bahwa perbedaan budaya organisasi akan mengakibatkan terjadinya perubahan performance financial.

\section{METODOLOGI}

Penelitian ini menggunakan pendekatan Pendekatan Penelitian: Kualitatif dengan strategi Studi Kasus. Penelitian dilakukan dengan pola studi komparatif, yaitu untuk membandingkan keberhasilan dalam menyelenggarakan kebijakan pelayanan publik dengan melihat keberhasilan PPSTP yang berhasil dengan kebupaten yang tidak berhasil

Penelitian ini dilakukan pada tiga kantor Pelayanan Perizinan Terpadu Satu Pintu (PPTSP) yang berlokasi di Kabupaten Solok Sumatera Barat, Kabupaten 50 Kota Sumatera Barat dan Kabupaten Sragen Jawa Tengah.

Kabupaten Solok Sumatera Barat dan Kabupaten Sragen Jawa
Tengah dipilih sebagai lokasi penelitian karena PPTSP di kedua kabupaten ini merupakan pelopor pelaksanaan PPTSP dan dinilai berhasil keluar dari budaya organisasi yang lama sehingga budaya organisasi yang baru berhasil membawa kedua organisasi ini berhasil dalam pelaksanaan PPTSP.

Sedangkan kabupaten PPTSP dai kabupaten 50 Kota Sumatera Barat merupakan PPTSP yang didirikan setelah Permendagri No.24/ 2006 tentang Pelayanan Perizinan Terpadu Satu Pintu (PPTSP) dikeluarkan dan saat ini masih terus tumbuh.

Disamping itu, perbedaan karakteristik budaya masyarakat juga diperhatikan. Masyarakat Sragen dikategorikan sebagai budaya pedalaman yang partenalistik. Sedangkan Solok dan 50 Kota dikategorikan sebagai budaya pesisir yang egaliter. Heterognitas masyarakat, Sragen merupakan daerah dengan heterogenitas yang tinggi sedangkan Solok dan 50 Kota lebih heterogen.

Penelitian ini menggunakan alat pengumpul data wawancara mendalam, wawancara kelompok, observasi, pengumpulan dokumen dan photo. Wawancara digunakan untuk mengungkap, menelusur dan mencari alasan dan latar belakang tentang kebijakan yang dipilih. Observasi, dokumentasi dan photo digunakan untuk memperoleh data dan informasi tentang landasan 
hukum, panduan yang digunakan, dan perencanaan yang diduga mempunyai kaitan dengan pelayanan publik. Informan dalam penelitian ini adalah Pimpinan lembaga dan staf.

Selanjutnya data diolah dengan melakukan interpretasi data yang telah diperoleh dan didokumentasikan. Untuk validasi dan akurasi data dilakukan trianggulasi data.

\section{HASIL DAN PEMBAHASAN} Reformasi Kelembagaan PTSP

Reformasi kelembagaan PTSP adalah bagaimana daerah membentuk lembaga yang memiliki tugas dan fungsi dalam memberikan pelayanan perizinan mulai dari memasukan berkas sampai kepada menerbitkan berkas. Konsep ini sejalan dengan isi Permendagri 24 tahun 2006. Pembenahan kelembagaan ini penting, karena dari pembenahan kelembagaan inilah reformasi pelanan usaha dapat dimulai. Mengingat selama ini pelayanan perizinan tersebar diberbagai dinas, badan, kantor atau unit.

Saat ini mekanisme pelayanan perizianan di ketiga kantor pelayanan perizinan relatif sama. Kesamaan tersebut disebabkan karena ketiga daerah sama-sama pernah mendapatkan bimbingan teknis dari TAF melalui program OSS. Dalam hal ini Kabupaten Sragen menjadi model dalam pengembangan pelayanan satu pintu. Hal penting yang dapat dicatat disini adalah reformasi birokrasi akan lebih cepat mendapat respon jika telah ada model yang akan dikembangkan. Dalam konteks ini ada Kabupaten Sragen. Selain model, reformasi birokrasi juga membutuhkan dukungan secara kebiajakan.

Apa yang terjadi di Kabupaten 50 Kota lebih dikarenakan faktor dukungan kebijakan. Pemerintahan daerah mendirikan kantor pelayanan perizianan lebih disebabkan karena ada Permendagri yang isinya mewajibkan daerah kabupaten/ kota untuk mendidirikan PPTSP. Terakhir, kesuksesan reformasi birokrasi juga dipengaruhi oleh keterampilan aparat dalam menjalannkannya. Dalam hal ini, kehadiran bimbingan teknis akan mempermudah dan mempercepat reformasi birokrasi. Ketiga daerah yang menjadi objek dalam penelitian ini adalah daerah penerima bimbingan teknis dari TAF dalam program OSS. Bantuan teknis ini bertujuan untuk memebantu daerah dalam melairkan institusi PPTS, bagiamana merancang mekanisme dan pelatihan dalam peneingkatan SDM/ staf. Reformasi pelayanan birokrasi mengalami Ioncatan berarti setelah mendapat bantuan teknis ini.

Waktu rata-rata pengurusan izin usaha dibawah lima belas hari. Satu jenis izin memakan waktu lebih dari dua minggu, yaitu IMB untuk non pribadi 15 hari, sedangkan jenis izin usaha lainnya diselesaikan dalam jangka waktu satu minggu. 
Berkaitan dengan waktu, dari verifikasi yang dilakukan terdapat tiga catatan penting; (1). Penetapan waktu atau lamanya perprosesan berkas tidak didasari atas perhitungan beban kerja dan prosedur perizinan. Akibatnya, ketetapan waktu tersebut tidak dapat dijadikan patokan bagi pengusaha atau si pengurus izin dalam mendapatkan kepastian waktu. Begitu juga dalam pemberian layanan, petugas tidak dapat memberi kepastian waktu siapnya sebuah izin. Pada tahapan pertimbangan adminitrasi (berkas) dapat diselesaikan dalam satu hari kerja. Tapi ketika memasuki tahap verifikasi atau peninjauan ke lapangan kecuali izin Ho, tidak dapat diukur ketepatannya. Seperti dalam pengurusan izin prinsip, berapa lama proses verifikasi dalam peninjauan lapangan tidak dapt ditetapkan.

Setidaknya ada tiga faktor yang ikut mempengaruhi, yaitu; pertama, banyaknya dinas atau instansi yang terlibat. Kondisi tersebut berdampak kepada persoalan koordinasi; kedua, wilayah Kabupaten Limapuluh Kota yang relatif luas menentukan cepatnya proses tersebut. Semakin jauh jarak lokasi dengan pusat pemerintahan maka semakin lama waktu yang dibutuhkan, dan ketiga, lemahnya koordinasi dengan si pengurus izin, sehingga berakibat dalam penetapan waktu penyampaian hasil verifikasi; (2). Berkaitan dengan panjangnya jalur birokrasi yang harus dilalui untuk mendapatkan tanda legalisasi; dan (3). Kesibukan pejabat yang dimintai legalisasi. Sebahagian besar keweangan penandatangan surat masih terpusat ke kepala daerah. Selain relatif sempitnya jadwa kepala daerah, konsekwensi penandatanganan oleh kepala daerah adalah panjangnya jalur birokrasi yang harus dilewati.

Bagaimana lamanya sebuah izin diurus dapat tergambar dalam sejumlah flowchart dibawah ini. Pada gambar tersebut terlihat bagiamana panjangnya prosedur yang harus dilalui dan itu berkonnsekwensi pada waktu, biaya dan peluang untuk terjadi kebocoran. Flowchart Pengurusan Izin Usaha, Keseluruhan tampilan flowcart tidak menunjukkan alur perizinan yang riil berjalan. Adapun perbedaan dengan kondisi riil terdapat pada mekanisme atau alur pengurusan izin. Perbedaan flowcart jelas terlihat pada jenis perizinan yang membutuhkan kunjungan kelapangan. Seperti rapat-rapat tim teknis untuk mepertimbangkan apakah sebuah izin akan direkomendasikan sering diputuskan langsung dilapangan. Termasuk hitungan berapa besar retribusi sering dilakukan dilapangan berdasarkan kondisi rill lapangan. Sedangkan jenis izin yang tidak membutuhkan tinjauan lapangan, gambaran flowcart dengan kondisi riil lapangan lebih memiliki kedekatan. 


\section{Contoh Flowchart SITU/ HO Sebelum Penyederhanaan}

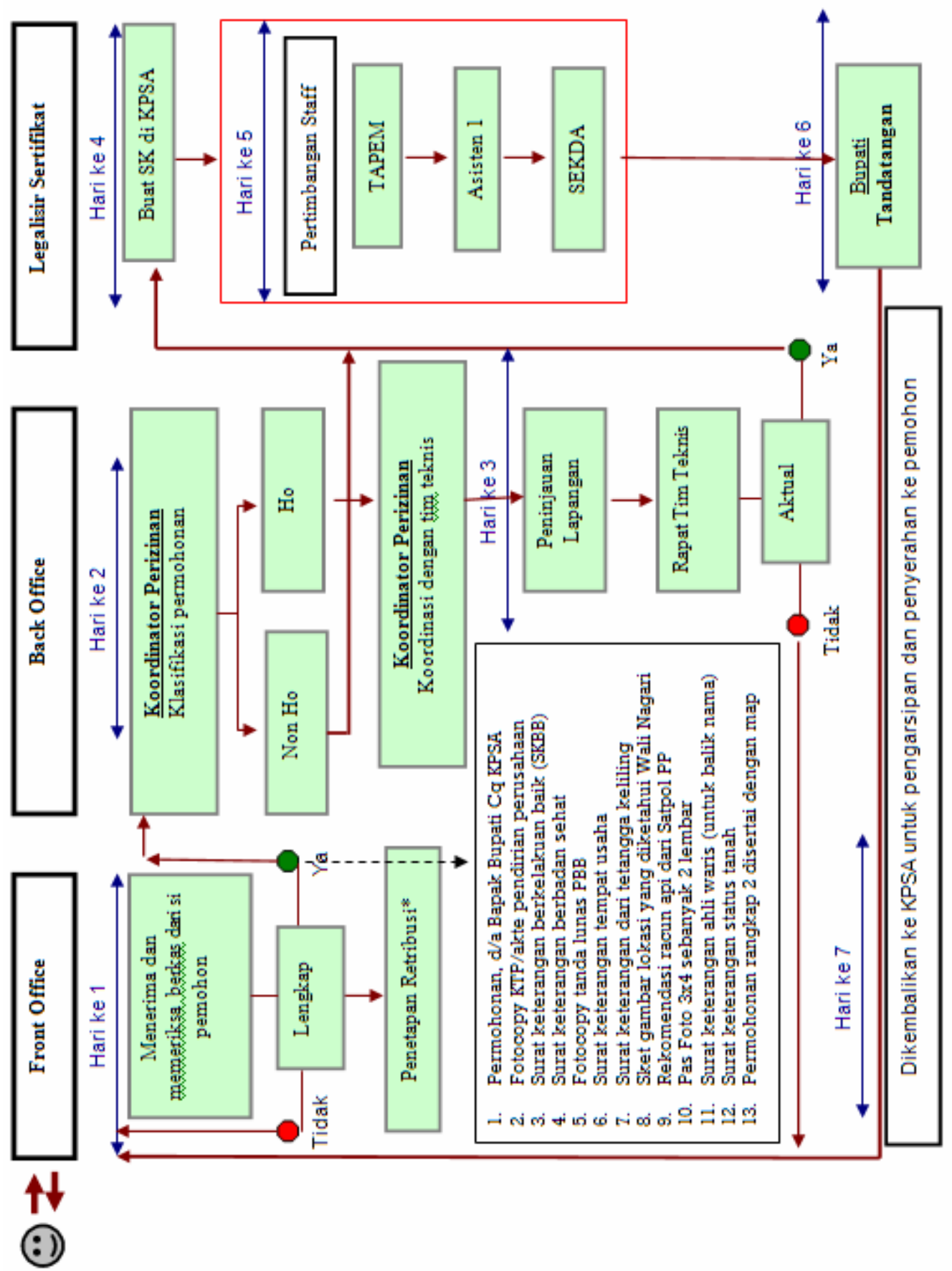




\section{Flowchart TDI, TDP \& SIUP}

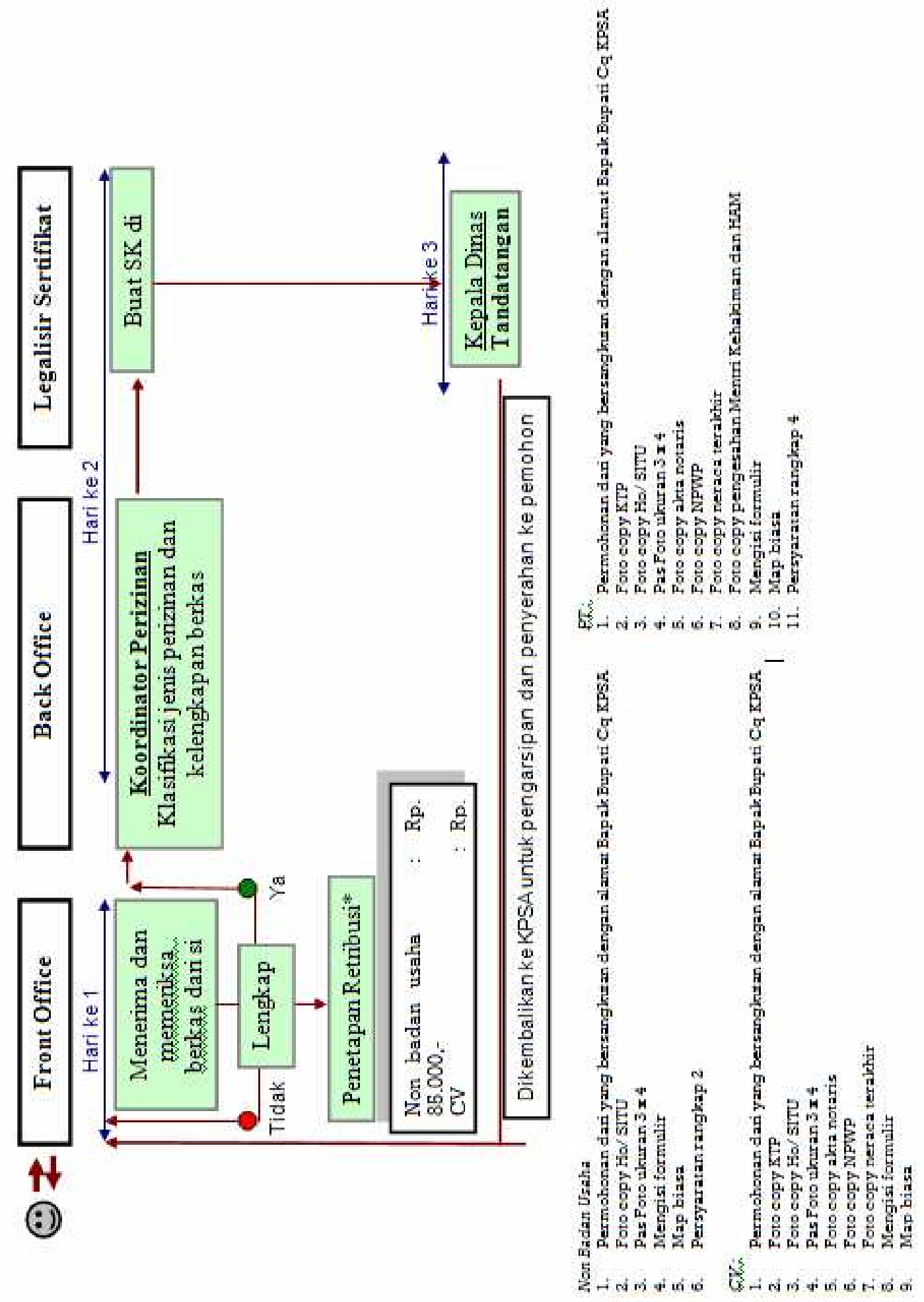




\section{Flowchart IMB}

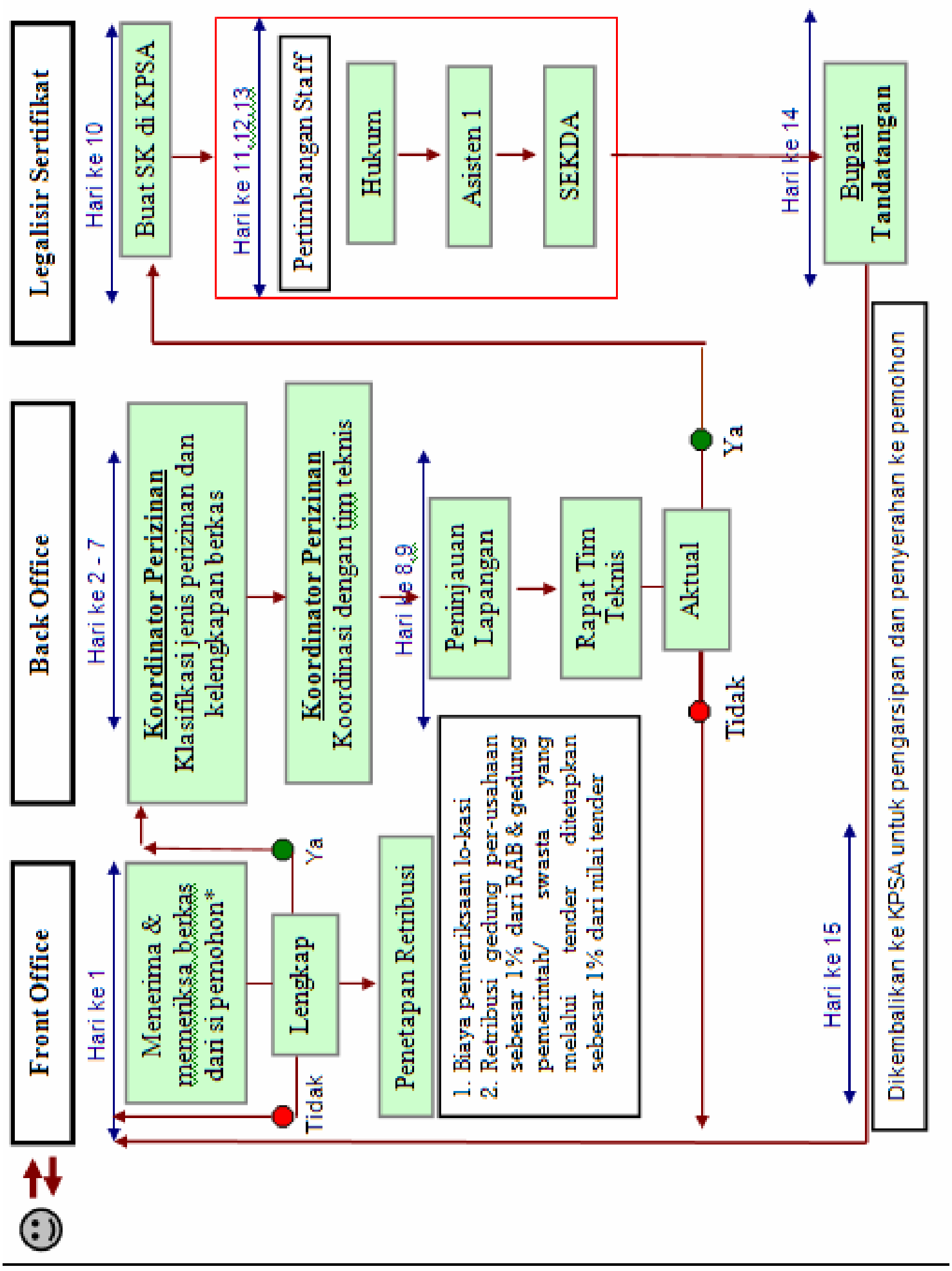


Berikutnya contoh dari alur perizinan setelah dilakukan penyederhanaan. Rasionalisasi persyartan, kewenangan pelimpahan penandatangan sertifikat kepada kepala kantor berdampak lamanya sebuah perizinan dapat diselesaikan. Dalam hal ini pelayanan kepada penerima jasa akan jauh lebih cepat terselesaikan.

Contoh Flowchart:

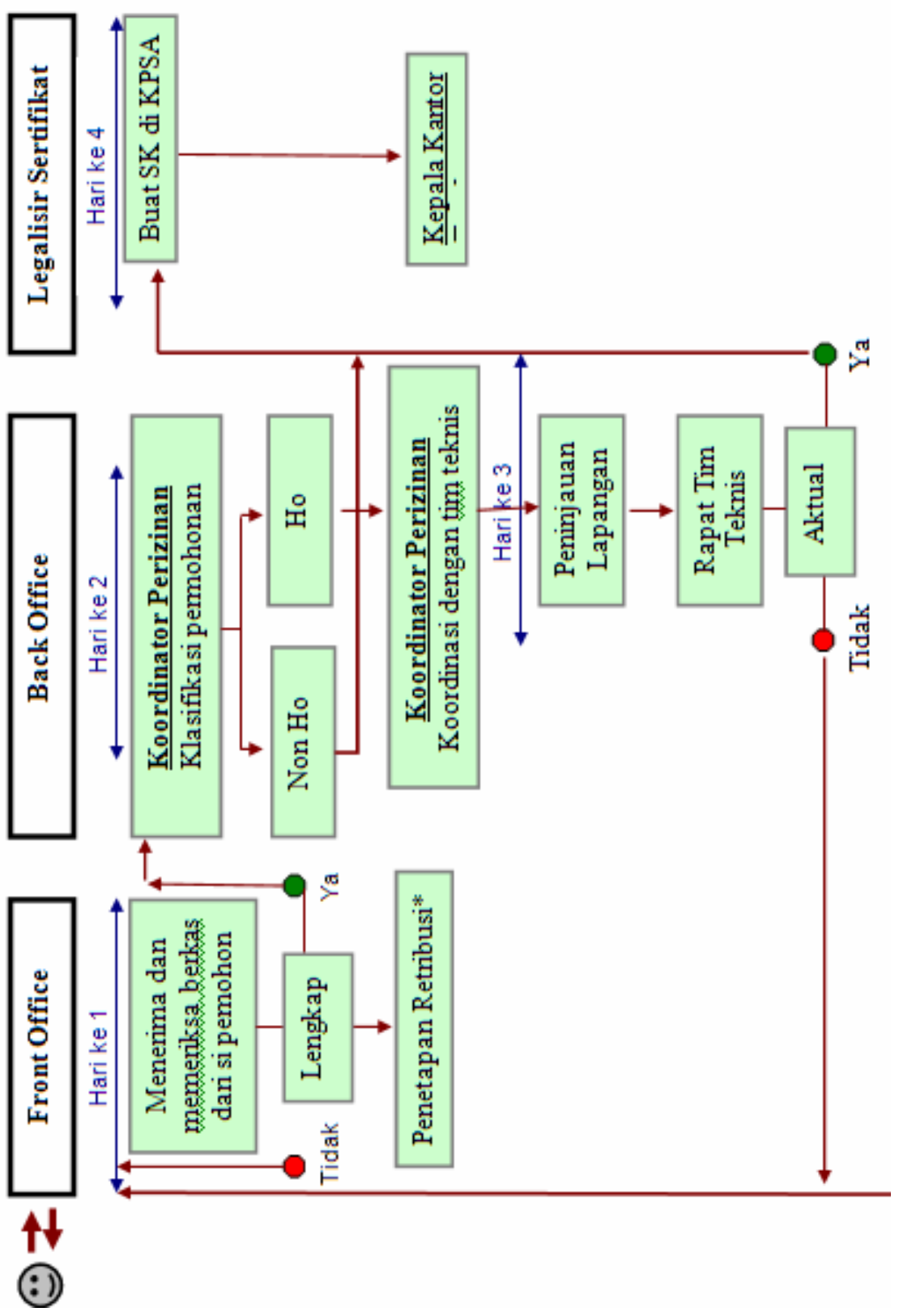


Gambaran diatas bisa jauh lebih pendek lagi, bahkan bisa menjadi hitungan jam, ketika izin yang akan diurus tidak memebutuhkan tinjauan kelapangan. Penyederahanaan ini diketiga daerah telah dilakukan. Dalam realitasnya apa yang dicantumkan dalam alur dapat berjalan. Namun dalam pelaksanaannya sering tidak sesuai lebih disebabkan karena tidak adanya kontrol yang kuat dari pimpinan. Untuk Kabupaten Sragen dan Kabupaten 50 Kota mereka menyediakan loket khusus untuk menyampaikan keluhan atas layanan yang diberikan.

\section{Budaya Organisasi}

Budaya organisasi merupakan salah satu faktor yang tidak dapat dipisahkan dalam penentu kesuksesan organisasi. Budaya organisasi merupakan sistem makna bersama yang dianut oleh anggotaanggota yang membedakan organisasi itu dengan organsasi lain. Budaya merupakan perekat sosial yang membantu organisasi itu dengan memberikan arahan dan standar yang tepat tentang apa yang harus dilakukan oleh karyawan yang berada di dalam organisasi tersebut sekaligus juga memandu dan memberntuk sikap serta perilaku karyawan.

Salah satu budaya yang semestinya dimiliki oleh PPTSP adalah budaya "tanggap terhadap pelanggan" yang diyakini merupakan salah satu upaya untuk mempertahankan kesetiaan pelanggan dan akhirnya berujung pada perolehan laba jangka panjang. Untuk melahirkan budaya tanggap terhadap pelaggan ada beberapa tindakan yang dapat diambil oleh pihak manajerial yang dirancang untuk menciptakan karyawan dengan kompetensi, kemampuan dan keinginan untuk menyelesaikan masalah pelanggan ketika muncul.

a. Proses seleksi yang hanya menerima calon karyawan yang ramah dan memiliki orientasi yang tinggi terhadap pelayanan kepada pelanggan.

b. Pelatihan dan sosialisasi yang terus menerus terhadap para karyawan yang telah ada saat ini, karena organisasi tidak mungkin melakukan perekrutan secara total dan mem-PHK kan karyawan yang ada.

c. Rancangan structural, dengan memberikan kendali yang lebih besar kepada karyawan. Hal ini dapat dicapai dengan mengurangi kaidah dan aturan. Pihak manajemen perlu memberikan keleluasaan kepada karyawan untuk melakukan tindakan yang diperlukan dalam rangka memenuhi kepuasan pelanggan.

d. Pemberdayaan karyawan dengan terus menerus memberikan keleluasaan untuk mengambil keputusan yang menyangkut kegiatan-kegiatan yang berhubungan dengan pekerjaan. 
e. Kepemimpinan

yang menyampaikan budaya organisasi melalui apa yang mereka katakan dan perilaku yang mencitrakan fokus pada pelanggan.

Penelitian ini menggali upayaupaya yang telah dilakukan oleh PPTSP dalam mengembangkan budaya organisasi pada masingmasing. Bentuk atau wujud budaya organisasi yang diamati meliputi:

1. Keteraturan Perilaku. Pada setiap kantor PPTSP, keteraturan perilaku secara umum didasarkan pada perundang-undangan Permendagri nomor 24 tentang Pelayanan Perizinan Terpadu Satu Pintu (PPTSP). Permedagri mengatur secara umum perilaku dan tata cara yang harus dilaksanakan setiap PPTSP dalam menyelenggarakan pelayanan perizinan kepada publik.

Disamping aturan-aturan yang ditetapkan secara nasional berdasarkan perundangundangan setiap PPTSP juga memiliki kode etik yang disusun bersama oleh pemerintah daerah. Indikator keberhasilan PPTSP dalam penerapan aturan-aturan yang ditetapkan adalah penyelenggaraan perizinan yang sesuai dengan standar yang ditetapkan UU.

2. Norma-Norma, Standar dan Ketentuan Perilaku. Norma-norma berbentuk SOP yang ditetapkan pada setiap level tugas. SOP yang disusun meliputi prosedur pelayanan yang diberikan kepada konsumen, lama waktu penyelesaian perizinan dan uraian secara rinci tugas-tugas yang dibebankan kepada setiap staf.

Setiap PPTSP telah melakukan perubahan regulasi terkait dengan SOP pelayanan. Dalam pelayanan terjadi pelimpahan wewenang dari setiap dinas kapada kantor pelayanan, tim teknis yang menjadi pendukung pelaksana kegiatan, penyederhanaan prosedur, dan anggaran biaya yang dibebankan kepada APBD.

3. Nilai-Nilai Baku. Nilai yang diinternalisasi dan disosialisasikan oleh para anggota. Dalam bidang pelayanan nilai-nilai baku yang seharusnya diterapkan kepada setiap karyawan adalah budaya tanggap terhadap pelanggan dan pelayanan prima. Wujud internalisasi nilai-nilai tersebut adalah dengan cara intagrasi dalam setiap bidang pekerjaan. Keunggulan PPTSP kabupaten Sragen dalam hal ini adalah setiap petugas telah ditraining sesuai dengan bidang tugas yang dikerjaannya. SDM yang ada ditata dengan konsep terpadu dan pararel untuk memudahkan dalam pelaksanaan tugas harian dengan prinsip one for all $n$ all for one, semua saling mengisi dan melengkapi serta membackup pekerjaan antar karyawan satu dengan yang lainnya. Dengan pegaturan seperti ini setiap pengguna 
layanan akan selalu dapat ditangani dengan baik. Sementara di PPTSP kabupaten Solok dan 50 Kota penataan seperti ini belum terlihat. Sebagian besar petugas menangani bagian yang menjadi tanggung jawab mereka masingmasing.

4. Filsafat. Kebijakan yang mencerminkan kepercayaan organisasi dalam memperlakukan karyawan dan konsumen. Dalam hal ini konsumen diperlakukan sebagai pihak yang harus dilayani dengan baik. Karena pelayanan yang diberikan akan memberikan imbal balik yang positif terhadap kantor pelayanan secara khusus dan daerah secara umum. Di sisi lain karyawan diajak dan diberi pelatihan yang terus menerus agar filsafat dan kebijakan yang ada selalu hidup dalam hati mereka. Salah satu upaya yang dilakukan oleh PPTSP Kabupaten Sragen adalah Trainning for succes yang secara rutin tiap hari Sabtu. Kegiatan ini memiliki dampak sangat luar biasa kepada para pegawai. Mereka terbiasa bekerja dengan rasa iklas tidak mengeluh dan saling mendukung untuk lebih maju.

\section{Sosialisasi Budaya Organisasi}

Budaya organisasi yang diwujudkan pada setiap PPTSP disosialisasikan kepada pimpinan dan seluruh karyawan dengan berbagai cara.

1. Pelatihan-pelatihan yang diikuti oleh pimpinan dan karyawan yang dimaksudkan untuk menanamkan nilai-nilai dan falsafah organisasi.

Tabel 1. Pelatihan Staf di PTSP Sragen, Solok dan 50 Kota

\begin{tabular}{cccl}
\hline Lokasi & Kab Sragen & \multicolumn{1}{c}{ Kab Solok } & \multicolumn{1}{c}{ Kab 50 Kota } \\
\hline Pelatihan Staf & - pelayanan prima, & - Pelatihan Pelayanan & - Seluruh staf yang ada \\
& ESQ, dan & Perizinan & saat ini telah \\
& Hypnoterapi & $-97 \%$ staf belum & mengikuti pelatihan \\
& - Ada yang seran & mengikuti pelatihan & - Staf yang ada telah \\
& dilakukan secara & pelayanan perizinan. & mengikuti kegiatan \\
& formal dan & & banding ke Sragen dan \\
& informal, indoor, & Kabupaten Solok \\
& outdoor, massal & \\
& dan individual dan & \\
& melibatkan semua & \\
& staf dan pimpinan & \\
\hline
\end{tabular}

2. Ritual, berupa deretan kegiatan berulang yang mengungkapkan dan memperkuat nilai-nilai utama organisasi. Dalam penelian ini, kegiatan ritual hanya dijumpa di

3. Lambang dan Kebendaan

Sosialisasi budaya organisasi dalam bentuk lambang dan 
kebendaan (Atribut) ditemui pada setiap PPTSP dengan tingkat yang berbeda-beda.Caracara ini merupakan upaya kantor PPTSP agar budaya organisasi yang sudah dibangun selalu diingat dan dilaksanakan oleh segenap individu di dalam organisasi. Bagaimana upaya yang dilakukan setiap PPTSP dalam mensosialisasikan budaya organisasi pada setiap lini, dapat diringkas pada table berikut.

Tabel 2 Upaya Pengembangan Budaya Organisasi di PPTSP Kabupaten 50 Kota, Kabupaten Solok dan Kabupaten Sragen

\begin{tabular}{|c|c|c|c|c|}
\hline No & $\begin{array}{c}\text { Unsur } \\
\text { Pengembangan } \\
\text { Budaya } \\
\text { Organisasi } \\
\end{array}$ & Kab 50 Kota & Kab Solok & Kab Sragen \\
\hline 1. & Pelatihan & $\begin{array}{lr}\text { Ada tetapi } & \text { tidak } \\
\text { dilakukan } & \text { secara } \\
\text { berkesinambungan } \\
\text { sehingga budaya } \\
\text { organisasi } & \text { tidak } \\
\text { terbentuk } & \text { dengan } \\
\text { sempurna } & \end{array}$ & 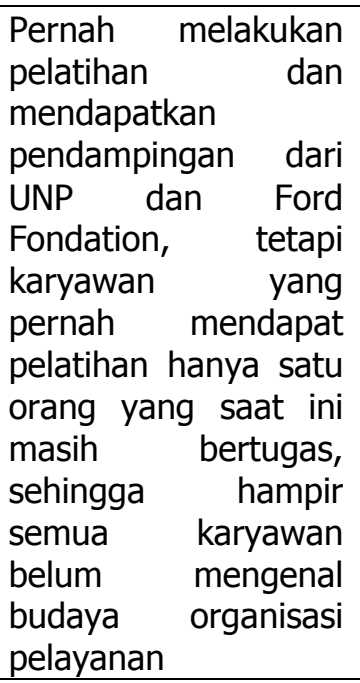 & $\begin{array}{l}\text { Pelatihan dilakukan } \\
\text { secara berkala dan } \\
\text { berkesinambungan. } \\
\text { Baik pelatihan } \\
\text { formal tentang } \\
\text { pelayanan maupun } \\
\text { pelatihan non } \\
\text { formal dalam } \\
\text { bentuk ceramah } \\
\text { dan diskusi. }\end{array}$ \\
\hline 2. & Ritual & Tidak ada & Tidak ada & $\begin{array}{l}\text { Ritul penanaman } \\
\text { budaya organisasi } \\
\text { dilakukan setiap } \\
\text { pagi jam } 07.30 \\
\text { dalam bentuk apel } \\
\text { pagi. Diberikan } \\
\text { kembali } \\
\text { pengingatan } \\
\text { tentang tugas- } \\
\text { tugas pelayanan } \\
\text { yang dilakukan } \\
\text { oleh setiap staf }\end{array}$ \\
\hline 3. & $\begin{array}{l}\text { Lambang } \\
\text { Kebendaan }\end{array}$ & $\begin{array}{l}\text { - Gedung milik } \\
\text { sendiri dan sudah } \\
\text { mencerminkan } \\
\text { lembaga } \\
\text { pelayanan, }\end{array}$ & $\begin{array}{l}\text { - Gedung belum milik } \\
\text { sendiri tetapi sudah } \\
\text { mencerminkansebu } \\
\text { ah lembaga } \\
\text { pelayanan }\end{array}$ & $\begin{array}{l}\text { - Gedung milik } \\
\text { sendiri dan sudah } \\
\text { mencerminkan } \\
\text { lembaga } \\
\text { pelayanan, }\end{array}$ \\
\hline
\end{tabular}




\begin{tabular}{|c|c|c|c|c|}
\hline No & $\begin{array}{c}\text { Unsur } \\
\text { Pengembangan } \\
\text { Budaya } \\
\text { Organisasi }\end{array}$ & Kab 50 Kota & Kab Solok & Kab Sragen \\
\hline & & 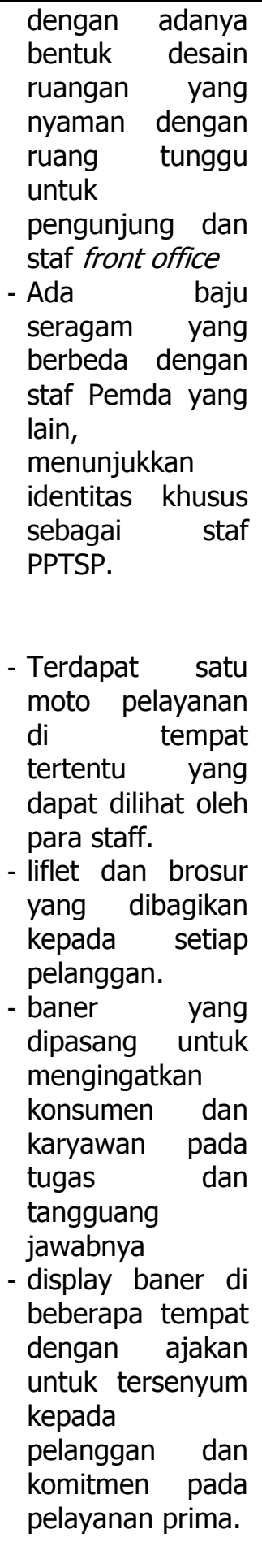 & 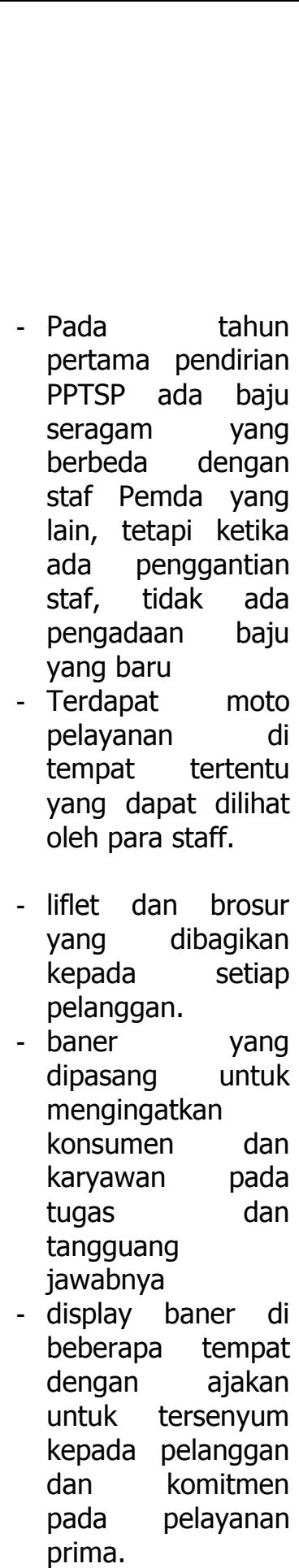 & 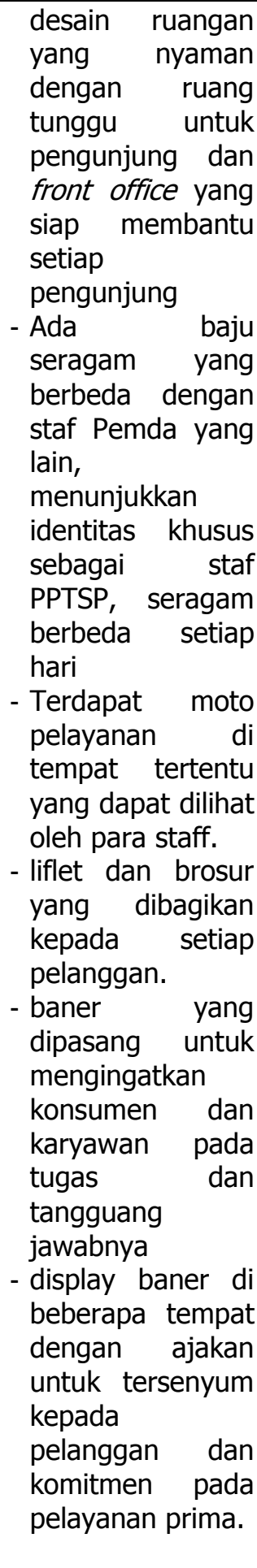 \\
\hline
\end{tabular}




\section{Analisis}

Pemikiran yang berpijak bahwa perbaikan administrasi publik dalam konteks institusional birokrasi menjadi kunci reformasi birokrasi telah mendorong pemerintah untuk mengeluarkan berbagai kebijakan. Salah satu diantaranya adalah kewajiban pemerintahan daerah kabupaten/ kota untuk membentuk PPTSP. Kebijakan ini berhasil "memaksa" pemerintahan daerah kabupaten/ kota untuk membentuk institusi PPTSP yang tugas dan fungsinya untuk melayani masyarakat dalam pelayanan perizinan. Sasaran dari pembentukan PPTSP adalah dunia usaha memiliki legalitas usaha.

Dalam konteks perbaikan administrasi publik, pembentukan institusi PPTSP dapat dikatakan efektif. Secara institusional, PPTSP dihadirkan dalam SOTK di pemerintahan daerah kabupaten dan kota. Jika diklasifikasikan dari proses pembentukan terdapat tiga kategori, yaitu ; (1) daerah kabupaten/ kota yang memperkuat institusi PPTSP. Jika sebelumnya institusi PPTSP hanya berbuntuk unit kemudian ditingkatkan menjadi kantor, badan atau dinas. Daerah kabupaten/ kota yang dapat diklasifikasi dalam kelompok ini misalnya Kabupaten Solok dan Kabupaten Sragen. (2) daerah kabupaten / kota yang menghidupkan kembali institusi PPTSP. Daerah kabupaten/ kota dalam kelompok ini adalah daerah yang dulunya pernah membentuk institusi PPTSP tapi kemudian dihilangkan dan kembali diadakan setelah kebijakan secara nasional muncul. Salah satu daerah yang dapat dikategorikan dalam kelompok ini adalah Kabupaten Limapuluh Kota. Sedangkan kategori (3) daerah kabupaten/ kota yang untuk pertama kali mendirikan institusi PPTSP. Contoh daerah dalam ketegori ketiga ini rata-rata dimiliki oleh daerah kabupaten/ kota di Indonesia. Artinya, sebahagian besar daerah kabupaten/ kota di Indonesia memang belum mengenal PPTSP.

Secara keseluruhan pembentukan PPTSP berjalan dengan cepat. Dalam hal ini sejumlah faktor yang mendukung percepatan tersebut adalah :

1. Ada kebijakan secara nasional agar pemerintahan daerah kabupaten/ kota untuk mendirikan PPTSP.

2. Ada daerah yang dijadikan model bagi pengembangan PPTSP. Pembentukan model pengembangan PPTSP ini tidak dapat dilepaskan dari pendampingan yang dilakukan oleh The Asia Fuondation (TAF) melalui program One Stop Service relatif menyeragamkan pola pembentukan PPTSP.

Secara keseluruhan pembentukan PPTSP dapat dikatakan berhasil di daerah kabupaten/ kota. Namun keberhasilan tersebut tidak merata dalam konteks pengembangan budaya organisasi. Jika 
pembentukan institusi PPTS lebih mengarah pada pembentukan organisasi dan mekanisme yang didukung oleh regulasi maka budaya organisasi lebih mengarah pada prilaku. Dalam hal ini Kabupaten Sragen lebih mengarah pada pembentukan budaya organisasi jika dibandingkan dengan dua daerah lainnya (Kabupaten Solok dan kabupaten Limapuluh Kota). Keberasilan Kabupaten Sragen tidak lepas dari kemampuan daerah ini dalam menginternalisasikan nilainilai pelayanan kepada staf PPTSP. Hal serupa tidak terlihat di dua daerah lainnya - Kabupaten Solok dan kabupaten Limapuluh Kota.

Dari analisis, terlihat beberapa faktor yang menyebabkan terjadinya perbedaan dalam pengembangan budaya organisasi di PPTSP Kabupaten Sragen, Kabupaten Solok dan Kabupaten 50 Kota.

1. Secara internal, tingkat partisipatif staf berbeda antar satu kantor PPTP. Di kabupaten Sragen tingkat partisipasi staf lebih tinggi dibandingkan dengan dua kantor pelayanan perizinan lainnya. Hal ini disebabkan karena adanya keterlibatan langsung setiap staf pada tugas pelayanan. Kebijakan penataan SDM dengan konsep terpadu dan pararel memudahkan dalam pelaksanaan tugas harian yaitu one for all $n$ all for one, sehingga setiap staf memilki tugas sendiri tetapi juga membackup pekerjaan antar karyawan satu dengan yang lainnya.

2. Kebijakan tentang pengembangan staf, internalisasi nilai-nilai, optimalisasi pemaknaan atribut. Kebijakan ini terkait dengan pelatihanpelatihan staf agar nilai-nilai falsafah pelayanan terinternalisasi pada setiap karyawan. Pelatihan ini juga berkaitan dengan bagaimana mengoptimalisasi makna atribut-atribut yang digunakan di kantor pelayanan.

3. Secara eksternal, tipe kepemimpinan di setiap lokasi kantor PPTSP. Tipe kepemimpinan berpengaruh signifikan terhadap kebijakan yang pemerintah. Kabupaten Sragen memperoleh dukungan yang sangat besar dari pemerintah daerah setempat dan diberikan kewenangan untuk mengeluarkan izin dari kantor pelayanan. Kewenangan ini juga terlihat dari tingkatan Eselon II untuk Kepala Kantor Pelayanan Terpadu Satu Pintu kabupaten Sragen. Kewenangan ini belum diberikan kepada dua kantor PPTSP lainnya.

4. Secara teknis, ketersedian infrastruktur pendukung.

Secara umum untuk menunjang terlaksananya pelayanan yang optimal setiap daerah telah menyediakan sarana perkantoran yang sangat memadai. Pusat perkantoran ini ditunjang dengan fasilitas ruang tunggu, loket 
pelayanan, jaringan internet dan sarana lainnya.

Kabupaten Sragen dan 50 Kota telah memilki gedung perkantoran milik sendiri yang sangat nyaman dan mudah diakses. Sedangkan PPTSP kabupaten Solok menempati gedung bersama dengan pemda dengan sarana yang cukup memadai.

Akhirnya satu model yang dapat diterapkan oleh setiap daerah ketika melakukan reformasi organisasi khususnya Pelayanan Terpadu Satu Pintu interanalisasi nilai-nilai budaya organisasi, khususnya budaya pelayanan dapat digambarkan sebagai berikut.

\section{Gambar 4 Model Pengembangan Integrasi Budaya Organisasi pada Pelayanan Terpadu Satu Pintu}

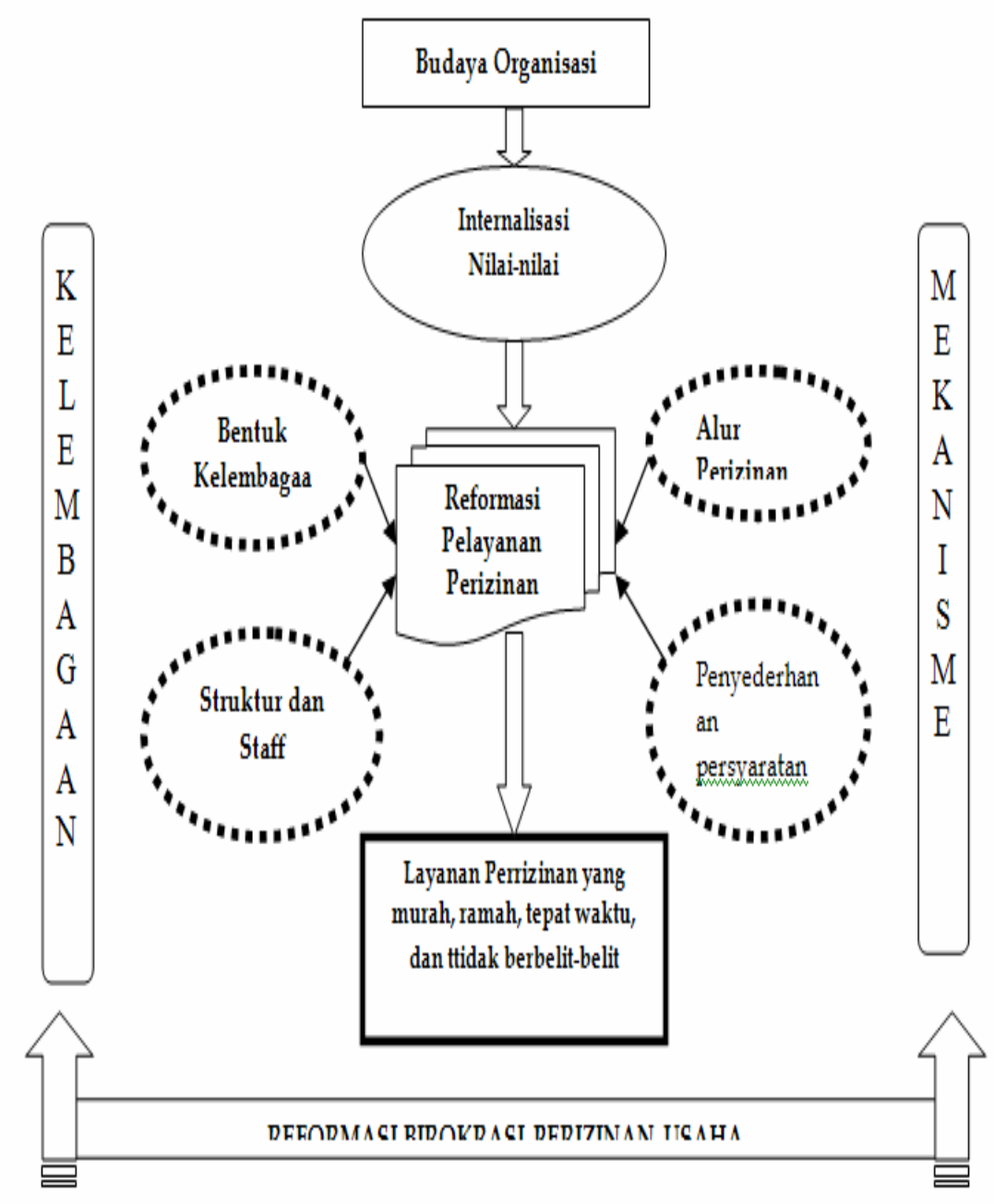




\section{KESIMPULAN DAN SARAN Kesimpulan}

Dari penelitian ini dapat disimpulkan bebarapa poin pokok yang sepatutnya menjadi perhatian dalam pengembangan dan aplikasi kebijakan Pelayanan Terpadu Satu Pintu berkaitan dengan reformasi institusi dan pengembangan budaya organisasi.

1. Kebijakan Permendagri nomor : 24/ 2006 tentang Pelayanan Perizinan Terpadu Satu Pintu, telah berhasil membentuk kelembagaan PPTSP. Namun tidak serta merta memperbaiki budaya organisasi birokrasi. Dari ketiga PPTSP yang diteliti terdapat perbedaan dalam mengembangkan budaya organisasi baru yang sejalan dengan pembentukan institusi PPTSP.

2. Kabupaten Sragen terlihat berhasil dalam pengembangan institusi pelayanan terpadu satu pintu dengan adanya dukungan dari pemerintah daerah berupa kebijakan pemberian wewenang yang luas kepada institusi dalam pengelolaan perizinan. Keberhasilan ini juga ditunjang dengan pembentukan dan internalisasi budaya organisasi, khususnya budaya pelayanan prima kepada pimpinan dan seluruh staf yanng terlibat. Reformasi institusi ditunjang dengan internalisasi budaya organisasi terlihat merupakan satu kunci dalam keberhasilan PPTSP Kabupaten Sragen dalam mengelola pelayanan perizinan dengan baik.

3. Kabupaten Solok yang merupakan pionir pembantukan pelayanan terpadu satu pintu terlihat kurang berkembang dengan baik, karena reformasi institusi tidak diikuti dengan penanaman budaya organisasi kepada pimpinan dan staf yang ada.

4. Sedangkan Kabupaten 50 Kota yang beberapa tahun sebelumnya memiliki kinerja yang kurang bagus dalam bidang pelayanan terpadu terus melakukan pembenahan institusi dan keterlibatan staf. Hal ini terlihat dari rekruitmen staf yang lebih selektif dan pemberian pelatihanpelatihan dan training dengan model out door untuk internasliasi budaya organisasi yang sudah terbentuk. Dampaknya adalah terjadi perubahan dalam kehadiran lembaga PPTSP. Jika dulu kehadiran lembaga dianggap sebagai tempat "pembuangan" SDM yang kurang cakapbergeser ke arah pandangan kehadiran staf yang berkopetensi. Hal ini berdampak pada fungsi kelembagaan. Namun penanaman nilai-nilai tidak diinternalisasikan secara kontinyu.

\section{Saran}

1. Untuk perbaikan birokrasi memang perlu ada satu daerah 
yang menjadi model bagi daerah lain

2. Perbaikan di sisi reformasi kelembagaan terutama pada organisasi pelayanan publik juga memerlukan pembentukan dan internaliasi budaya organisasi agar reformasi birokrasi sejalan dengan perbaikan fungsi-fungsi organisasi terutama falsafah dan nilai-nilai pelayanan masyarakat.

\section{DAFTAR PUSTAKA}

Anne S. Tsui, Hui Wang1 and Katherine R. Xin2, (2006) Organizational Culture in China: An Analysis of Culture Dimensions and Culture Types: Management and Organization Review

Krzysztof Tomasz Konecki (2006) Reproduction of Organizational Culture What Does Organizational Culture Recreate? Problems and Perspectives in Management / Volume 4, Issue 4.

Pasi Pyoria, (2007), Informal Organizational Culture: The Foundation of Knowledge Workers'performance, Journal of Knowledge Management, Vol. 11 No. 3 2007, pp. 16-30, $Q$ Emerald
Group Publishing Limited, ISSN

Robert J. Taormina (2008) Interrelating leadership behaviors, organizational Socialization, and organizational culture. Leadership \& Organization Development Journal Vol. 29 No. 1, 2008 pp. 85-102 ; Emerald Group Publishing Limited

Seyda Seren, Ulku Baykal Relationships Between Change and Organizational Culture in Hospitals, Journal of Nursing Scholarship, 2007; 39:2, 191-197. C_2007 Sigma Theta Tau International.

Satu Teerikangas and Philippe Very (2006), The CulturePerformance Relationship in M\&A: From Yes/No to How, British Academy of Management.

One Stop Services :Suatu Kebijakan Pro Bisnis dan Strategi Peningkatan PAD http://diswandi.wordpress.co $\mathrm{m} / 2010 /$

Pelayanan Perizinan Terpadu Satu Pintu Suatu Upaya Reformasi Birokrasi

http://ekavidyaputra.blogger. com/ 